\title{
The Language Attitudes of Minangkabau People Towards Minangkabau and Indonesian Language
}

\section{Temmy Thamrin}

Bung Hatta University, Padang, Indonesia

Email: temmy_hariri@yahoo.co.id

How to cite this paper: Thamrin, T. (2018). The Language Attitudes of Minangkabau People Towards Minangkabau and Indonesian Language. International Journal of Language Teaching and $\begin{array}{lrl}\text { Education, } & 2(2), & 157-175 .\end{array}$ https://doi.org/10.22437/ijolte.v2i2.506 5

Received: May 16,2018

Accepted: June 22, 2018

Published: July 31,2018

Copyright (C) 2018 by author and IJoLTe This work is licensed under the Creative Commons Attribution International License (CC BY 4.0).

http://creativecommons.org/licenses/by/4.0/ c) (i)

\begin{abstract}
This paper examines the language attitudes of Minangkabau people toward Minangkabau language (MIN) and Indonesian (BI) in West Sumatra, Indonesia. The data were collected in the form of questionnaires, in-depth interviews and participant observation with a sample of 200 Adult respondents in six research areas. This research uses a Likert scale with the categories classified into five alternatives $(1=$ Strongly Disagree, $2=$ Disagree, $3=$ Uncertain, $4=$ Agree, and $5=$ strongly agree) and there are some tables analyzed based on yes/no questions, no $=0$ and yes $=1$. There are twelve questions on the questionnaire pertaining to the attitudes of adults. The results show that the adult attitudes can be classified into three categories, (1) positive; (2) negative; and (3) ambivalent attitudes. The third category is dominant. The term 'ambivalent" is used for intermediate results. It is shown that the respondents expressed their feeling in both positive and negative comments in the same utterance when answering the questions related to MIN. For these responses, it is seen that there is a mixed feeling where they use "but" or "although" after expressing their positive feelings thereby countering their first statement. The evidence of the ambivalent and mixed feelings from respondents is shown. This means that Minangkabau people tend to avoid the conflict of having negative opinions; they tend to say what they mean in more indirect ways. On the other side, there is a positive attitude in response to the questions about BI. Majority of respondents have very strong positive attitudes towards BI.
\end{abstract}

\section{Subject Areas}

Sociolinguistics

Keywords

Language Attitudes, Minangkabau Language, and Ambivalent Responses

\section{Introduction}

There are several reasons why the study of language attitudes is important in sociolinguistics, because a positive or negative attitude can influence linguistic behavior in a community. Attitudes can affect the language choice in that community, likely future changes 
in language use, and language loyalty (see Melander, 2003: 2, Obiols, 2002). This study can identify how people's feel and view about language in general, their own language and others' languages as well. There are a variety of feelings and attitudes towards their own language. These may be positive or less positive attitudes. Some examples of positive attitudes are that people are very proud of their own language; they feel that their own language shows their identity and feel that it is the best language to be used in the family or society. However, on the other hand, there are also less positive attitudes towards the native language. Some people or communities feel that their language is not prestigious, and they are shy to speak their native language because it is considered as a low prestige language.

The aim of this research is to describe the role of attitudes towards two languages, Minangkabau as the local language and Indonesian as the official language. Specifically, this research observes language attitudes among adults Minangkabau people. One of the most important discussions about the language attitudes of MIN in the past decades is in Anwar (1985). Anwar describes the problem of language attitudes and use between Indonesian and regional languages including the use of Indonesian by Minangkabau people in West Sumatra. In his old data, the use of MIN and attitude of Minangkabau people towards MIN is different from the present situation. He says that "the Minangkabau do not normally use Indonesian in the home no matter what the topic of the conversation is but speak in Minangkabau throughout because that is the proper language to be used at home. An educated Minangkabau does not even use Indonesian if it is carried out in informal situations" (1985: 155). Furthermore, he says "a Minangkabau who tries to use Indonesian all the time when speaking to other Minangkabau is normally regarded as a crank or even crazy" (1985: 156).

The picture of the language situation at that time indicated that people have positive attitudes and preferred to use MIN rather than BI. This situation contrasts with the situation that is found at present in West Sumatra. Parents mostly teach BI as the first language to their children. In other words, BI is becoming the home language and the predominant language in other domains of language use. As a native MIN citizen from West Sumatra Province, the researcher has great concern about the language choices and language attitudes of Minangkabau people, since most of the younger generation does not tend to use MIN as their primary language for communication because most adults and parents do not give their children the opportunity to speak this language at home. This phenomenon impelled the researcher to do the research on language attitudes.

Minangkabau is one of the main ethnic groups of Indonesia, considered as the fourth biggest major ethnic group of Indonesia after Javanese, Sundanese and Madurese (Steinhauer, 1994: 759). Information from the 2014 census shows the total population in West Sumatra is 5,098,790. Most Minangkabau people are bilingual or even multilingual (Marnita, 2011: 299). In standard sources, MIN has not been listed as an endangered language in Indonesia. In the latest edition of The Ethnologue (2013), the status of this language is 5 (Developing) in the EGIDS scale. This means "the language is in vigorous use, with literature in a standardized form being used by some though this is not yet widespread or sustainable" (Ethnologue, 2013). Moreover, in the report for language development, it is stated that this language is taught in primary schools in Grades 1 and 2 (Ethnologue, 2013); however, this statement is incorrect. According to my observations and having interviewed primary school teachers from different areas in West Sumatra to cross check this information, all of them stated that MIN is not taught in primary schools. 
The only one subject related to Minangkabau culture, named Budaya Alam Minangkabau (The culture of Minangkabau Nature), is taught in Years 4 to 6. In this subject, students learn how to respect the traditional culture, they learn the values and the beliefs of Minangkabau people, and how to interact within Minangkabau society; it is more concerned with the Minangkabau culture and there is no teaching of MIN itself. Therefore, it can be said that MIN is not taught in formal education.

Even though the number of speakers of MIN is great, with approximately more than 5 million speakers, it does not mean that this language is not at risk. If the local people do not have positive attitudes, the number of speakers of this language might decrease and the language, which is regarded as "a safe or a healthy language", might become "endangered". Some facts show that a language that has many speakers can be at risk. This can be seen in a recent study of Children's Language in Bilingual Community in East Java. In his dissertation, Setiawan (2013) did comprehensive research of the language use and attitudes of children in a Javanese bilingual community. Oglobin (2005), as cited in Setiawan (2013: 300), claimed that Javanese is spoken by $40 \%$ of the Indonesian population, which means that if the population in Indonesia is approximately 238 million, Javanese is spoken by around 95 million people (Setiawan, 2013: 301). His findings show that the use of Javanese language has declined because children's proficiency in Indonesian is better and Javanese parents do not promote Javanese language as the children's first language. These results are in line with those of Ravindranath and Cohn (2014) who also did research into the symptomatic language shift in the Javanese of younger speakers. By looking at the condition of the language with the largest speakers in Indonesia, the researcher assumed that this might also be happening with the Minangkabau language when the native language is not maintained, it can eventually become lost.

\section{Literature Review}

Language is not just an instrument of communication; it is also a symbol of social or group identity (Grosjean, 1982: 117). In some community where different languages coexist, language attitudes play an important role in the lives of the speakers of the language. If there is a different judgment or feeling in the community towards a language, this will be shown in the attitudes of the community towards the language itself. For example, some people may feel ashamed of speaking their local language and may believe that the best language is the national language because it is the way to achieve a better life. They may feel that the national language is more prestigious, and that the local language is not appropriate to be taught to children as their first language. They may even feel that the best language is the national language because by having the ability to speak the national language, children will have a better opportunity to get a good job in the future. Each of these beliefs can affect people's attitudes towards languages, especially towards a native language.

Over many years, studies have shown that positive attitudes towards the local language can lead to the maintenance of the language itself (Libster \& Dailey-0'Cain, 2009; Ehala \& Niglas, 2006; Kuncha \& Bathula, 2004; Garrett, Coupland, \& Williams, 2003; Coady, 2001; Ladegaard, 2000). The recent studies cited here discuss language attitudes in different places and different domains. They show that people's attitudes toward language and individual identity have a strong effect on the maintenance of a language, and on any potential revitalization of the language. 
Kuncha and Bathula (2004) discussed the role of attitude in language shifts and language maintenance in a new immigrant community in New Zealand. The study investigated the language attitudes of mothers and children in the Telugu community and observed how they were losing their language while living in an English-speaking country. There are five majors areas are discussed: a) language proficiency, b) attitude towards English, c) attitude towards Telugu, d) attitude towards bilingualism and e) language maintenance. The study shows that for the language proficiency, the use of Telugu language is greater in reading and writing skills than in speaking and listening skills. It is hardly to find that any of the children used Telugu. Both mothers and children have positive attitude towards English. They felt 'proud' to use the English language. The response to the question about attitudes towards Telugu indicate that there is mix feeling where in one side both of respondents have positive attitudes towards this language, while on the other said, they do not feel that Telugu is not necessary to be learned. For the attitude towards Bilingualism, it indicates that there is shift from Telugu to English. In the language Maintenance, it indicates that there is such a negative attitude the language maintenance. The results of this study almost the same with the findings of my research where the Minangkabau society felt 'proud' to their language, but they felt that MIN is not necessary to be learnt. It is clear that 'necessity' and 'pride' have been the two influencing factors of language shift

Ehala and Nigelas (2006: 209-277) observed the language attitudes of Estonian secondary school students. They argue that "globalization has changed the immediate communication domain from a national state level to a transnational level. Because of this global change, the traditional understanding of ethnolinguistic vitality may no longer be entirely adequate". Moreover, they mention that ideological issues regarding group identity become the key that determines which communities retain their language and which are to lose it in the future. There are many reasons why attitude is a fundamental issue (Baker, 1992: 9-10). Concerning the life of a language, Baker explains that "attitudes to that language appear to be important in language restoration, preservation, decay, or death. If a community is grossly unfavorable to bilingual education or the imposition of a "common" national language attempted, language policy implementation is unlikely to be successful". Moreover, Baker mentions that a survey of attitudes provides an indicator of current community thoughts and beliefs, preferences, and desires. Further, Baker says that language attitude is an umbrella term, which can focus on various specific types of attitudes. He gives eight examples of the most frequently discussed topics in language attitude research (Baker, 1992: 29; Duan, 2004: 17). These are as follows:

1. Attitude to language variation, dialect and speech style

2. Attitude to learning a new language

3. Attitude to a specific minority language

4. Attitude to language groups, communities and minorities

5. Attitude to language lessons

6. Attitude to the uses of specific language

7. Attitude of parents to language learning

8. Attitude to language preference

From the eight topics above, three are strongly seen in my research study: attitude to Minangkabau groups, communities and minorities; attitudes of parents to language learning, where most Minangkabau parents do not teach MIN to their children; and attitudes 
about language preferences, where in West Sumatra, BI is the preferred language in most domains discussed in this study.

According to Baker (1992: 41), age, gender, schooling, ability, language background, and cultural background affect whether one's attitude towards the local language is favorable or unfavorable. Each of these indicators will now be looked at in turn. For his age indicator, Baker gives examples from his research in 1988, showing that positive attitudes to the Welsh language among young Welsh people aged between 10 and 15 years were changing at the time. He found an inverse relationship: as age goes up, the favorability of attitude towards Welsh comes down. This is unlike the situation in Minangkabau society, where the attitude of adults about MIN is in decline and the preference to teach BI is increasing.

Gender can also affect language attitudes (Baker, 1992: 42). Baker illustrates this situation, showing that girls had more favorable attitudes towards the Welsh language than boys. The present study found the opposite case in preferences for using BI and MIN. My research findings show that it is the girls, especially in the city, who prefer to use BI when they speak with other girls. However, when the girls speak to boys, they use more MIN. Conversely, when boys speak to girls they prefer to use BI, while boys prefer to use MIN with other boys.

The educational context may also bring changes in language attitudes (Baker, 1992: 43). Attitudes to language use can be influenced by school. Because of the language policy in Indonesia, the government's preference for having BI as the main medium for instruction is positively affecting people's attitudes towards BI. Ability or proficiency in a language can also affect language attitudes (Baker, 1992: 44). This happens when children learn a dominant language such as BI as their first language. Automatically, the proficiency of the speakers who learn $\mathrm{BI}$ as their first language is higher than among those who learn it as a second language. People's degree of fluency in a language will affect language attitudes. Another factor that may affect the attitude formation is people's language background, for example the language usage of family, community, and the density of language use in the neighborhood. These may be influential in attitude formation (Baker, 1992: 44). The last factor suggested by Baker is cultural background. Cultural activities such as religion, reading and watching or listening to media in a language may also affect the preference for using a language (Baker, 1985; Baker, 1992: 45).

The attitude of a speech community towards its languages is the crucial factor in language maintenance (Bradley, 2002: 1). Moreover, Bradley mentions that there are three social factors in language attitudes: domains of language use, network for language use, and the degree of accommodation towards the speech of the interlocutor (2002: 4). In terms of domains of language use, speakers might feel that a language is appropriate for a domain of language use. The preference for using a language depends on the context. Contact and interaction between people in a social network is another major factor in language maintenance. In some cases, there are some ethnic groups who have more closed social networks, while others have social networks that are more open as they have more communication with outsiders (Bradley, 2002: 5). This network pattern can affect the rapidity of changing or shifting to a language. The third factor is accommodation to the speech of the interlocutor. If in one community the people are open to receiving the new culture, and more outsiders are coming, there is more need to adjust to the new culture, which will affect language attitudes and language choice. 
Positive attitudes about the local language in the speech community might help its survival, while negative attitudes might lead to a language shift (Setiawan, 2013: 34). There is evidence that positive attitudes towards the local language can help the revival of a language, as cited in Bradley (2001: 7), Crystal (2002) has reported the success of the Welsh revival over the last thirty years and the recent efforts to revitalize Basque in Spain. Harlow (2005: 136) has reported that the Maori Language Commission evaluated revival efforts for Maori language in 1995 with 2,400 respondents. This shows that the Maori people have positive attitudes towards their language, not only among adults but also among youth. Less positive attitudes towards local languages can be seen in the research done by some scholars in Indonesia. Kasih (2005) examined the language shift from Javanese to Indonesian that is taking place in Java, Indonesia. She reported that the language choices of parents, mothers as the main caregivers in the family, could contribute to language attitudes. Despite the efforts and energy of the local government in promoting Javanese in schools, this study shows that the children, and particularly girls from middleclass backgrounds, prefer Indonesian to Javanese and appear to have less favorable attitudes towards Javanese than children from working-class backgrounds.

Another recent study about Javanese children's attitudes towards the Javanese language has been reported by Setiawan (2013). In his study, he examined the children in a bilingual community in East Java. The results are very surprising: most of his respondents judge Javanese negatively and Indonesian positively. The respondents consider that Javanese is difficult, old fashioned and not a "cool" language. They also believe that Javanese does not give self-confidence and prestige to its speakers. It is the language of the poor and the village language. The respondents also believe that it is not a language for science, technology, or business. On the contrary, positive attitudes towards Indonesian are given in every statement. There is some correlation between findings in this study and my findings about Minangkabau people attitude towards MIN.

Anderbeck (2010) examined language use and attitudes in two Jambi Malay communities near the capital city, Jambi, of Jambi Province in Sumatra, a region where many minority languages are at risk of language shift in the context of a rapidly changing society. This is near the Minangkabau area in West Sumatra. The findings of the study show that the young and the educated generally have lower usage of Jambi Malay and less positive attitudes towards it, while the women tend to have higher usage of Jambi Malay and more positive attitudes towards it. Marnita (2006), in a study on language attitudes about Minangkabau in relation to the use of Minangkabau formal speech levels and the choice of medium for informal education, shows that the language profile in Minangkabau can be divided into homogeneous and heterogeneous areas. The people who live in homogenous areas still maintain the use of MIN, especially with adults and older villagers, while those who live in the heterogeneous areas have a shift of language use towards BI among youths and adults. Moreover, Marnita demonstrates further evidence that most youth are considered to lack understanding of Minangkabau formal speech levels and proverbs. In line with Marnita's study, Oktavianus (2005), in his comprehensive research on Minangkabau proverbs, shows that of 880 respondents in urban and suburban areas, only $30 \%$ to $50 \%$ of youth aged 20-25 can understand Minangkabau proverbs. As my findings, the lack of understanding about Minangkabau culture, such as proverbs, is not only found among youth but also among young parents, who ask their children to go to the older people (grandparents) if they have difficulty understanding Minangkabau culture. Oktavianus suggests that the parents have a role in transmitting the native language and 
avoiding difficulties in understanding it, but in my study this role has been passed on to grandparents.

\section{Method}

There are many alternative methods for measuring individual attitudes, including Thurstone \& Chave (1929), Likert (1932), Guttman's Scalogram analysis, the Semantic Differential technique, the Repertory Grid technique, Factor Analysis and Sociometry (Baker, 1992: 17).

According to Baker (1992:17-18), one of the most popular methods of attitude measurement is to produce an attitude scale composed of statements for which responses may be "agree" or "disagree" or are measured using a five point scale: strongly agree, agree, neither agree nor disagree, disagree, strongly disagree. Following Baker's method, the researcher created questions that are designed to assess attitudes towards MIN and attitudes towards BI. The answers are represented by the numbers 1 to 5 , showing a range of responses from "no opinion" to "strongly agree". The response scale is as follows: $5=$ Strongly agree, $4=$ Agree, $3=$ Uncertain, $2=$ Disagree, and $1=$ Strongly disagree. Other questions in this section are designed to get information on participants' opinions about learning MIN as the first language, in the form of yes/no questions. In this section of the survey, participants are also asked to fill in blank spaces by writing their own reasons for "yes" or "no" answers.

Besides using questionnaire, other methods used in the process of data collection included participant observation and in-depth interviews. As Labov (1972: 32) states, "The effort to observe how speakers talked when they were not being observed is the Observer's Paradox. Among the partial solutions to this paradox within the face-to-face interview, the elicitation of narratives of personal experience proved to be the most effective". The researcher used both methods to try to observe various phenomena, using participant observation for data that could not be obtained through questionnaires and formal interviews. Observation method is one of the important methods for studying language attitudes in the society. By having the data from observation method, the researcher can cross check the data given by informants through the questionnaire.

An in-depth interview was used to explore important information regarding the sociological variables that the researcher expected would correlate with the participant's attitudes and behavior. The researcher especially tried to get participants to tell me about their opinions on the MIN and BI language, which language they prefer and asked the parents who speak BI exclusively to their children why they have chosen this language for communication. As quoted from (Boyce, C., \& Neale, P. 2006: 3).

In-depth interviewing is a qualitative research technique that involves conducting intensive individual interviews with a small number of respondents to explore their perspectives on an idea, program, or situation. In-depth interviews are useful when you want detailed information about a person's thoughts and behaviours or want to explore new issues in depth. Interviews are often used to provide context to other data (such as outcome data), offering a more complete picture of what happened in the program and why.

The researcher was mainly able to interview mothers. According to Kuncha and Bathula (2004:3) mothers have the main role in introducing and maintaining culture, tradition, and language to their children. Therefore, their role is very important. 
To investigate the language attitudes in the Minangkabau community and how the language is maintained, the researcher collected data in six research locations in West Sumatra, three from high language contact areas (cities): Padang (PDG), Bukittinggi (BKT), and Payakumbuh (PYK). I also collected data from three lower language contact areas (regencies): Muaro Sijunjung (MSJ), Pulau Punjug (PPJ), and Lubuk Sikaping (LBS).

Table 3.1. Demographic information of respondents based on sex, age, and occupation

\begin{tabular}{|c|c|c|c|c|c|c|c|}
\hline Groups & Sex & $\mathrm{N}$ & $\%$ & Age Range & Occupation & $\mathrm{N}$ & $\%$ \\
\hline \multirow{6}{*}{ Adult } & & & & \multirow{5}{*}{$\begin{array}{l}35-60 \\
\text { Years Old }\end{array}$} & $\begin{array}{l}\text { Government Of- } \\
\text { ficers }\end{array}$ & 79 & 39 \\
\hline & Female & 102 & 51 & & Private Officers & 65 & 32 \\
\hline & \multirow{3}{*}{ Male } & \multirow{3}{*}{98} & \multirow{3}{*}{49} & & House Wives & 35 & 18 \\
\hline & & & & & Traders & 16 & 8 \\
\hline & & & & & Farmers & 5 & 3 \\
\hline & $\begin{array}{l}\text { Total Re- } \\
\text { spondents }\end{array}$ & 200 & 100 & & & 200 & 100 \\
\hline
\end{tabular}

\section{Findings and Discussions}

The opinions, feelings, and ideas about MIN and BI reflect respondents' attitudes about these languages. Positive attitudes in transmitting and learning MIN will allow MIN to be maintained, thereby sustaining local heritage. A general attitude can be calculated by comparing the results of adults' attitudes towards MIN and BI.

These findings answer the following three main research questions:

1. What are the attitudes of adults toward Minangkabau language and Indonesian language?

2. Do adults have positive attitudes towards their own language?

3. Do adults have different attitudes towards Minangkabau language?

These Participants answered the questionnaire that deal directly with the main three questions about attitudes towards language listed above. The attitudes of people about their local language play a very important role in the maintenance and the vitality of that language.

The Language that is Spoken Most Often in the Family

This is the question about the language is spoken most often in the family. This result is the combination of two different questions from the survey. The question about the best language used and the most often language used at home. Since the results almost identical, the researcher combines these two questions into one table finding. The following table shows the preferred language used in the families of respondents from the six research locations. 
Table 4.1. The language that is spoken most often in the family

\begin{tabular}{|c|c|c|c|c|c|c|c|}
\hline Languages & $\begin{array}{l}\text { PDG } \\
(\%) \\
\end{array}$ & $\begin{array}{l}\text { BKT } \\
(\%) \\
\end{array}$ & $\begin{array}{l}\text { PYK } \\
(\%) \\
\end{array}$ & $\begin{array}{l}\text { MSJ } \\
(\%) \\
\end{array}$ & $\begin{array}{l}\text { PPJ } \\
(\%) \\
\end{array}$ & $\begin{array}{l}\text { LBS } \\
(\%) \\
\end{array}$ & $\begin{array}{c}\text { Total } \\
(\%)\end{array}$ \\
\hline Minangkabau & 21 & 25 & 38 & 59 & 59 & 31 & 42.5 \\
\hline Indonesian & 79 & 75 & 62 & 41 & 41 & 69 & 57.5 \\
\hline
\end{tabular}

These Results from the adult group show that in four locations, these adults believe that they speak BI more often and better than MIN. The highest percentage of respondents who reported that they use BI most often in their home is in PDG. 79\% respondents reported that BI is the language used most often in their family. In BKT, PYK, and LBS, most respondents also said that $\mathrm{BI}$ is the best language for them: $75 \%$ in $\mathrm{BKT}, 62 \%$ in $\mathrm{PYK}$, and $69 \%$ in LBS. However, in MSJ and PPJ, the adults reported that the language used most often is MIN. By looking at the data, no substantial difference can be found between the numbers of respondents who use MIN and the number of those who use BI in MSJ and PPJ.

The next question in the set of language attitude questions is whether Minangkabau sounds friendly. The reason for the question, which relates to feelings, is because the tendency of people to use MIN, especially in high language contact areas, is low or, in other words, it is not preferred. During interviews, when participants are asked why they do not use MIN for daily speaking. The following are some statements from my respondents who mentioned that MIN is not good to listen to. Majority the respondents mention these reasons, when the researcher asked this question.

1. Saya sering mendengar orang yang berbahasa Minang dengan mengucapkan carut, seperti yang di ucapkan oleh preman-preman dan orang-orang yang tidak bersekolah. Saya khawatir kalau anak-anak meniru ucapan-ucapan kasar seperti itu.

"I often hear Minang speakers who use swearwords like what the gangsters or uneducated people uttered. I am very worried that my children will imitate and say those rude words". (ER, 45 years)

2. Ambo ndak mangatokan bahaso awak ko ndak elok, tapi kadang-kadang tadanga agak saketek kareh. ndak lamak didanga dek anak-anak. 'I do not say that our "language is not good, but sometimes it sounds very loud. It is not good if the children listen to it". (AMR, 39 years)

The following table shows the respondent's feelings about whether MIN sounds friendly. 
Table 4.2. Minangkabau sounds friendly

\begin{tabular}{lcccccc}
\hline \multicolumn{1}{c}{ Scales } & $\begin{array}{c}\text { PDG } \\
(\%)\end{array}$ & $\begin{array}{c}\text { BKT } \\
(\%)\end{array}$ & $\begin{array}{c}\text { PYK } \\
(\%)\end{array}$ & $\begin{array}{c}\text { MSJ } \\
(\%)\end{array}$ & $\begin{array}{c}\text { PPJ } \\
(\%)\end{array}$ & $\begin{array}{c}\text { LBS } \\
(\%)\end{array}$ \\
\hline 1. Strongly Disagree & 24 & 0 & 18 & 0 & 0 & 3 \\
2. Disagree & 34 & 31 & 27 & 38 & 19 & 22 \\
3. Uncertain & 26 & 56 & 41 & 22 & 50 & 59 \\
4. Agree & 16 & 13 & 15 & 38 & 28 & 16 \\
5. Strongly Agree & 0 & 0 & 0 & 3 & 3 & 0 \\
\hline
\end{tabular}

Table 4.3. Indonesian sounds friendly

\begin{tabular}{lcccccc}
\hline \multicolumn{1}{c}{ Scales } & $\begin{array}{c}\text { PDG } \\
(\%)\end{array}$ & $\begin{array}{c}\text { BKT } \\
(\%)\end{array}$ & $\begin{array}{c}\text { PYK } \\
(\%)\end{array}$ & $\begin{array}{c}\text { MSJ } \\
(\%)\end{array}$ & $\begin{array}{c}\text { PPJ } \\
(\%)\end{array}$ & $\begin{array}{c}\text { LBS } \\
(\%)\end{array}$ \\
\hline 1. Strongly Disagree & 0 & 0 & 0 & 0 & 0 & 0 \\
2. Disagree & 0 & 0 & 6 & 0 & 6 & 0 \\
3. Uncertain & 3 & 3 & 6 & 13 & 0 & 3 \\
4. Agree & 71 & 78 & 53 & 88 & 94 & 88 \\
5. Strongly Agree & 26 & 19 & 35 & 0 & 0 & 9 \\
\hline
\end{tabular}

It is apparent from table 4.2 that different areas have different thoughts about whether Minangkabau sounds friendly. In PDG, majority of respondents, 34\% stated that they disagree that MIN sounds friendly. In another three areas, most respondents are uncertain whether MIN is friendly or not. The only area that shows a positive agreement that MIN is polite is PPJ, where the highest percentage of respondents in this place chose scale 4 (28\%). It is also evident that there is no substantial difference between the positive and negative attitudes of adults. Results show that there is a mixed attitude towards MIN. The ambivalent attitudes from the respondents suggest that people avoid sensitive issues with a neutral answer.

Comparing to table 4.3 only a few respondents reported that they do not agree that BI sounds friendly. More than half of the respondents from all areas chose scale 4, agreeing that BI sounds friendly. This data also shows that all of respondents from all areas have similar attitudes toward BI. The highest number of responses is in scale 4, agreeing that BI sounds friendly. People have a very positive attitude towards BI. Compared with table 4.2 that shows people's attitudes towards the sound of MIN, it appears that people have a more positive attitude towards the sound of BI than MIN. Overall data shows that adults have stronger positive attitudes about BI as a friendly language.

Table 4.4. Minangkabau should be taught as the first language

\begin{tabular}{lcccccc}
\hline Answer & $\begin{array}{c}\text { PDG } \\
(\%)\end{array}$ & $\begin{array}{c}\text { BKT } \\
(\%)\end{array}$ & $\begin{array}{c}\text { PYK } \\
(\%)\end{array}$ & $\begin{array}{c}\text { MSJ } \\
(\%)\end{array}$ & $\begin{array}{c}\text { PPJ } \\
(\%)\end{array}$ & $\begin{array}{c}\text { LBS } \\
(\%)\end{array}$ \\
\hline No & 63 & 69 & 59 & 47 & 38 & 56 \\
Yes & 37 & 31 & 41 & 53 & 63 & 44 \\
\hline
\end{tabular}

In table 4.4, the pattern continues in this section about whether MIN should be taught as the first language to children; respondents continue to have a less positive response. Four 
areas (PDG, BKT, PYK, and LBS) have a negative response. More than half of the respondents from these four areas answered "No". However, in MSJ and PPJ, respondents gave more positive responses by answering, "Yes". In MSJ, 53\% respondents agree that MIN should be taught to a child as the first language, while 47\% disagree. Overall, 111 (55.5\%) respondents do not believe that MIN should be taught as the first language, while 89 (44.5\%) agree.

Besides giving yes/no questions, the researcher asked the respondents to write the reasons why they answer yes or no. The following table is a summary of the reasons why adults answered "no".

Table 4.5. The reasons of a 'No' answer

\begin{tabular}{lcc}
\hline \multicolumn{1}{c}{ Comments } & $\mathrm{N}$ & $\%$ \\
\hline $\begin{array}{l}\text { 1. MIN is not a global language. } \\
\text { 2. If MIN is taught as the first language, the children will find } \\
\text { difficulties at school. It will difficult for them to learn BI when } \\
\text { they grow up. }\end{array}$ & 20 & 18 \\
$\begin{array}{l}\text { 3. MIN can be learned from the society; the children can speak } \\
\text { MIN when they grow up. They can learn it in the society. }\end{array}$ & 23 \\
$\begin{array}{l}\text { 4. MIN is not a formal language. It is only a local language and } \\
\text { only used in West Sumatra. }\end{array}$ & 10 & 9 \\
$\begin{array}{l}\text { 5. BI is more important because it is the official language } \\
\text { 6. BI is politer than MIN and it sounds good for } \\
\quad \text { communication. }\end{array}$ & 15 & 14 \\
7. Not many people understand MIN; it is better to learn the \\
language that can be spoken by many people in Indonesia.
\end{tabular}

According to the table above, most respondents mentioned that $\mathrm{BI}$ is more important than MIN because it is used as media instruction at school, it is politer, MIN is not a global language but only a local language, and that BI is more widely-spoken than MIN, as well as other comments. The following table shows a list of comments about why MIN should be taught to young people as the first language: 
Table 4.6. The reasons of a 'yes' answer

\begin{tabular}{llcc}
\hline \multicolumn{1}{c}{ Comments } & $\mathrm{N}$ & $\%$ \\
\hline 1. & \multicolumn{1}{c}{ To respect our local culture } & 9 & 10 \\
2. MIN is my native language. & 19 & 21 \\
3. Because I live in Minangkabau & 20 & 22 \\
4. It is my identity. & 15 & 17 \\
5. I am Minangkabau and you are not Minangkabau if you cannot speak & 18 & 20 \\
& MIN. \\
6. To speak with other people who live in Minangkabau, such as family or & 8 & 9 \\
& \multicolumn{1}{c}{ relative } & 89 & 100 \\
\hline
\end{tabular}

A range of reasons why respondents think that MIN should be taught as the first language can be seen from in table 7. The most popular reasons are that that they are living in Minangkabau, MIN is a native language, that MIN is their identity, that children need to be able to speak to other family members, and that children should respect the local culture.

To fully understand the attitudes of respondents towards these two languages, the question of whether BI should be taught to children as their first language was asked. Responses to this question can be compared with results for the previous section on whether MIN should be taught as the first language.

Table 4.7. Indonesian should be taught as the first language

\begin{tabular}{lcrrrrr}
\hline Answer & $\begin{array}{c}\text { PDG } \\
(\%)\end{array}$ & $\begin{array}{c}\text { BKT } \\
(\%)\end{array}$ & $\begin{array}{c}\text { PYK } \\
(\%)\end{array}$ & $\begin{array}{c}\text { MSJ } \\
(\%)\end{array}$ & $\begin{array}{c}\text { PPJ } \\
(\%)\end{array}$ & $\begin{array}{c}\text { LBS } \\
(\%)\end{array}$ \\
\hline No & 13 & 31 & 38 & 47 & 66 & 19 \\
Yes & 87 & 69 & 62 & 53 & 34 & 81 \\
\hline
\end{tabular}

Comparing to the question in table 4.7, majority of respondents from five areas (PDG, BKT, PYK, MSJ, and LBS) agree that BI should be a child's first language, while in (PPJ), most respondents don't agree. Overall, there are $130(65.0 \%)$ respondents who have positive responses and 70 (35.0\%) who answered negatively. More than two thirds of all believe that BI should be taught to a child as their first language. Similarly, with the question about MIN, the researchers also asked the respondents give the reasons why they answer yes or no. The following is the reasons of 'yes' responses. 
Table 4.8. The reasons of a 'yes' response.

\begin{tabular}{llcc}
\hline \multicolumn{1}{c}{ Comments } & $\mathrm{N}$ & $\%$ \\
\hline 1. & BI is a formal and official language. & 16 & 12 \\
2. It will be easier to communicate with people who are not Minangkabau. & 19 & 15 \\
3. BI should be learned since you are young, so that you will be more & 26 & 20 \\
$\quad \begin{array}{l}\text { fluent when you grow up. Fluency in BI is important for finding a job. } \\
\text { 4. To understand school more easily }\end{array}$ & 23 & 18 \\
5. BI is a polite language. & 21 & 16 \\
6. BI is the preparation for Merantau 'area outside the Minangkabau & 12 & 9 \\
heartland' & 13 & 10 \\
\hline It is a trend to use BI now and it is used by modern people & 130 & 100 \\
\hline & Total &
\end{tabular}

From the table above, there are some reasons that are given by a high number of participants. These include reasons such as that $\mathrm{BI}$ is used at school, that $\mathrm{BI}$ is important for finding a job, that $\mathrm{BI}$ is a polite language, that $\mathrm{BI}$ is a formal, that $\mathrm{BI}$ is a lingua franca, that using $\mathrm{BI}$ is a trend and more modern, and that $\mathrm{BI}$ is used for Merantau. Of the respondents who believe that BI should not be taught as the first language, the following comments are given:

Table 4.9. The reasons of a 'no' response.

\begin{tabular}{rlcc}
\hline \multicolumn{1}{c}{ Comments } & $\mathrm{N}$ & $\%$ \\
\hline 1. & BI can be learnt at school. & 16 & 23 \\
2. We live in Minangkabau; BI is not the majority language. & 14 & 20 \\
3. We are Minangkabau people, MIN is more important & 19 & 27 \\
4. Nowadays, the teenagers use BI; I wonder that the young generation & $\begin{array}{l}\text { cannot speak MIN for the future. Therefore, MIN should be learnt as } \\
\text { the first language at this moment. }\end{array}$ & 9 & 13 \\
5. BI is not our mother tongue. & 12 & 17 \\
\hline Total & 70 & 100 \\
\hline
\end{tabular}

From the table above, we can see that the majority of "No" responses are given because MIN is their native language, so BI should not be taught as the first language, also because $\mathrm{BI}$ can be learned at school, and because $\mathrm{BI}$ is not the local language. Interestingly, some respondents who realize that $\mathrm{BI}$ is used by the younger generation nowadays express a fear that young people will not be able to use MIN anymore.

Another interesting question about the attitudes of people toward MIN is the use of Kato Nan Ampek. As mentioned in the earlier discussion about Kato Nan Ampek, this term refers to the registers for politeness, or etiquette to the different statuses of interlocutors (see Chapter 3). Kato Nan Ampek is about speaking with good manners. 
Table 4.10. Kato Nan Ampek should be taught to children

\begin{tabular}{lcccccc}
\hline Answer & $\begin{array}{c}\text { PDG } \\
(\%)\end{array}$ & $\begin{array}{c}\text { BKT } \\
(\%)\end{array}$ & $\begin{array}{c}\text { PYK } \\
(\%)\end{array}$ & $\begin{array}{c}\text { MSJ } \\
(\%)\end{array}$ & $\begin{array}{c}\text { PPJ } \\
(\%)\end{array}$ & $\begin{array}{c}\text { LBS } \\
(\%)\end{array}$ \\
\hline No & 21 & 3 & 0 & 0 & 0 & 0 \\
Yes & 79 & 97 & 100 & 100 & 100 & 100 \\
\hline
\end{tabular}

After learning that there is a negative response and mixed feelings about the MIN language, results for this section are surprising. The data shows that almost all respondents answered very positively about whether Kato Nan Ampek should be taught to children. The positive response pattern is found for the adults. In four areas (PYK, MSJ, PPJ, and LBS) all respondents answered, "Yes", while in BKT, only 3\% respondents answered "No", and in PDG, 21.1\% respondents said "No". The total number of adult respondents who believe that Kato Nan Ampek should be taught to children is 191 (95.5\%) and only 9 (4.4\%) don't believe this should be the case. These results suggest that almost all respondents believe that Kato Nan Ampek, should be learned, despite the pattern seen in previous sections.

When questions are about the Minangkabau language, there are less positive responses from respondents-consistently less positive responses are found in MSJ, PPJ, and somewhat less positive responses are found in PYK and LBS-but when the question relates to Kato Nan Ampek, which is one part of Minangkabau language itself, respondents nearly all give very positive responses. Perhaps this could be because respondents think that MIN is an impolite language, while appropriate use of Kato Nan Ampek is politer.

This question deals with the amount of pride respondents have in their Minangkabau language.

Table 4.11. Pride in Minangkabau Language

\begin{tabular}{lcccccc}
\hline Answer & $\begin{array}{c}\text { PDG } \\
(\%)\end{array}$ & $\begin{array}{c}\text { BKT } \\
(\%)\end{array}$ & $\begin{array}{c}\text { PYK } \\
(\%)\end{array}$ & $\begin{array}{c}\text { MSJ } \\
(\%)\end{array}$ & $\begin{array}{c}\text { PPJ } \\
(\%)\end{array}$ & $\begin{array}{c}\text { LBS } \\
(\%)\end{array}$ \\
\hline No & 11 & 3 & 0 & 0 & 0 & 0 \\
Yes & 90 & 97 & 100 & 100 & 100 & 100 \\
\hline
\end{tabular}

After learning as can be seen from the table above, interesting results are found again, where almost all respondents claim to have very positive attitudes towards MIN. It is seen from the results, where $100 \%$ of respondents in four areas (PYK, MSJ, PPJ, and LBS) report that they are proud of MIN. There are only $11 \%$ respondents in PDG and $3 \%$ respondent in BKT who answered "No" for this question. In sum, the total number of respondents who answered "Yes" is $97.5 \%$ and only 5 (2.5\%). These results suggest that Minang people claim to be very proud of their own language.

These results are in contrast with results from the previous analysis about MIN attitudes found in the previous description, where an ambiguous feeling towards MIN is shown. In one side, Minangkabau people felt proud of MIN. In the same time, they do not think that this language is important to be taught and spoken as the first language. In some societies, it is important for them to have the language as a part of society and for other society language is not important. As quoted from Smolicz (1992: 280) he argues that: 
"the cultural groups differ in the extent to which they emphasize their native tongues as core values. One may, for example, be an Irish nationalist and be unable to speak Irish Gaelic, although the Irish language continuous to act as a potent symbol of ethnic identity even for those who are either unable to speak it, or who have learned it at school but do not use it as everyday purposes (O'Buachalla 1984; Harris and Murtagh 1987 in Smolicz 1992). In much the same way, there are people in various countries of the world with a strongly developed sense of Jewish identity who uphold the continuity of Jewish tradition, but who speak neither Hebrew nor Yiddish, nor, indeed, any other specific Jewish - developed language or dialect. No one can deny, however, the powerful role played by Yiddish in the maintenance of the Jewish heritage for many countries in Central and Eastern Europe

Relating to this quotation, in the case of Minangkabau language, it seems that this language is not a core value of the society. They still feel Minangkabau as Minangkabau and proud to be in part of the society, but the language is not a part of their identity.

As a native Minangkabau speaker, pride for this language does not seem to be enough if the society does not have strong positive attitudes toward this language. Pride is only a feeling. We need actions and commitment from the society especially the parents to give children a chance to learn this language in their early years. It is dispiriting that some children introduce themselves as Minangkabau people, but they cannot speak their own language, even though they really are proud to be Minangkabau and proud of the Minangkabau language. Parents must realize it is their responsibility to transfer this language to their children. Currently, many parents do not seem to realize that their children's identity may be threatened. How can the young generation build their relationships with relatives in their hometown if they do not speak MIN? The attitudes of parents towards their own native language play a very important role for maintaining this language into the future. By dropping the native language in favor of the generic national language, their children may soon lose their identity.

\section{Conclusion}

The general conclusion is that there are ambivalent or mixed feelings among all respondents about MIN, especially when they answer sensitive questions about MIN. The adult's respondents mainly chose the "uncertain" option for these sorts of questions. Responses are different to questions about their attitudes to $\mathrm{BI}$, where they have positive attitudes towards this language.

When, the researcher initially found uncertain answers, the interview questions and observational data about these topics show that there is a tendency for people to say they have less positive attitudes towards MIN. For example, the respondents stated that BI is more important, that $\mathrm{BI}$ is politer, and that $\mathrm{BI}$ is the language of the future. From these answers, the implied meaning is that, instead of saying outright that MIN is impolite and sounds unfriendly, respondents prefer to say that BI is politer and that it is better for communication. This means that Minangkabau people tend to avoid the conflict of having negative opinions; they tend to say what they mean in more indirect ways.

On the question of whether MIN should be taught as the first language to children, most respondents don't support the idea. Adults are less inclined to believe that children 
should be taught MIN as their first language. They are not so concerned with transmitting this language to their children in the early years of childhood. Therefore, a general lack of use of, and interest in, MIN is increasing. An Indonesian proverb says, "Tidak kenal maka tak sayang", (If you do not know it, you will not love it), which is true for MIN itself. If the parents do not introduce this language to their children, how can these children know and recognize it as their own native language?

Contradictory thoughts are found for questions about Kato Nan Ampek (the four words, speech levels), where almost all respondents believe that Kato Nan Ampek should be taught to children. This means that, when questions ask about their feelings towards the Minangkabau language, there are mixed feelings and a hesitancy to answer "agree" or "disagree", while when there are questions about Kato Nan Ampek, which is a concept dealing with the way Minangkabau people speak to different interlocutors, an overwhelmingly positive response is received. It is difficult to understand what this means. Perhaps people believe that MIN might not be as polite a language as BI. Therefore, by teaching the concept of Kato Nan Ampek to children, it is hoped that they will know and use the appropriate register for different interlocutors, thereby following the rules of how Minang people should talk to each other.

These results suggest that many Minangkabau people still retain their own customs. As stated by Arifin and Gani (2007:18), Minangkabau society is still relatively strong, as it upholds and implements customs. The customs in this context are the normative values that govern how the society lives. As the norms of speaking in Minangkabau society include the use of Kato Nan Ampek, the majority of respondents claim that they use it. The contradictory results between the use of MIN and Kato Nan Ampek suggest that Minangkabau people make a differentiation between Minangkabau language and Kato Nan Ampek. They see these two concepts as distinct, where MIN is considered less important, while Kato Nan Ampek is the cultural norm that should be maintained and transmitted to the younger generation. They mostly do not understand that Kato Nan Ampek is a part of Minangkabau language itself. I also conclude that the less positive attitude towards MIN.

Besides that, almost all respondents claim that they are proud of MIN. Unfortunately, the pride of these people in their own language is not applied in their daily lives, as we can see in the discussion of domains of language use, especially at home domain. As previously mentioned, it is not enough only to have pride. People need action in their real lives to maintain MIN as a healthy language, to stop Minangkabau people having mixed feelings about their own language, to make people answer in an optimistic way that this language is a good language for communication, to give the opportunity for children to learn this language from birth, and to prevent future generations becoming monolingual in BI. According to Bradley (2002: 9), "we can try to change attitudes, we can help people to maintain their languages, but only if they want to". This means that there is no one that can help a society to maintain their language if the people in that society do not want to maintain it. 


\section{References}

[1] Anderbeck, K. L. (2010). Language use and attitudes among the Jambi Malays of Sumatra. Dallas, Texas: SIL International. Retrieved from http://ftp.sil.org/silepubs/Pubs/52809/52809 Anderbeck Sumatra.pdf.

[2] Anderson, J. D. (2006). Qualitative and quantitative research. London: Imperial COE.

[3] Anwar, K. (1980). Language use in Minangkabau society. Indonesia and the Malay World, 8(22), 55-63.

[4] Anwar, K. (1985). Indonesian: The development and use of a national language. Yogyakarta: Gadjah Mada University Press.

[5] Arifin, Zainal \& Gani, M. H. (2007). Relasi dua kepentingan: Budaya politik masyarakat Minangkabau. Jurnal Humaniora, 8(3), 15-25.

[6] Arifin, Zainal. (2009). Dualitas dalam masyarakat Minangkabau: Studi kasus praktik perkawinan di dua nagari (Unpublished doctoral dissertation). Gadjah Mada University.

[7] Arifin, Zainal. (2012). Dualitas praktik perkawinan Minangkabau. Jurnal Humaniora, 21(2), 150-161.

[8] Arifin, Zainal. (2014). Beberapa pendekatan antropology tentang fenomena simbolik. Jurnal Antropologi: Isu-Isu Sosial Budaya, 1(14), 17-22.

[9] Baker, C. (1992). Attitudes and language. Clevedon: Multilingual Matter.

[10] Bhugra, Dinesh, \& Matthew, A. B. (2005). Migration, cultural bereavement and cultural identity. World Psychiatry ,4(1), 18-24. Retrieved from http://www.ncbi.nlm.nih.gov/pmc/articles/PMC1414713/

[11] Boyce, C., \& Neale, P. (2006). Conducting in-depth interviews: A guide for designing and conducting in-depth interviews for evaluation input. Watertown, MA: Pathfinder International.

[12] Bradley, David, \& Maya, B. (2002). Language endangerment and language maintenance. London, New York: Routledge Curzon.

[13] Bradley, David, \& Maya, B. (2001). Changing attitudes to Australian English. In D. Blair, \& P. Collins (eds.), English in Australia, 271-285. Amsterdam: John Benjamins.

[14] Crouch, S. E. (2009). Voice and verb morphology in Minangkabau, a language of West Sumatra, Indonesia (Unpublished doctoral dissertation). University of Western Australia.

[15] Duan, Lei. (2004). A sociolinguistic study of language use and language attitudes among the Bai people in Jianchuan County, China (Unpublished doctoral dissertation). Payap University, Chiang Mai, Thailand.

[16] Ehala, Martin, \& Niglas, K. (2006). Language attitudes of wstonian secondary school students. Journal of Language Identity and Education, 5(3),209-227. Lawrence Erlbaum Associates, Inc.

[17] Ewing, M. C. (2005). Colloquial Indonesian. In K.A. Adelaar and, \& N. Himmelmann (eds.), The Austronesian Languages of Asia and Madagascar, 227-258. London: Routledge.

[18] Garret, P., Coupland, N., \& Williams, A. (2003). Investigating language attitudes: Social meanings of dialects, ethnicity, and performance. Cardiff: University of Wales Press.

[19] Grosjean, F. (1982). Life with two languages: An introduction to bilingualism. Cambridge, Mass: Harvard University Press. 
[20] Harlow, R. (2005). Covert attitudes to maori. International Journal of the Sociology of Language, 172, 133-147.

[21] Heider, Karl. G. (2011). The cultural context of emotion: Folk psychology in West Sumatra. London: Palgrave Macmillan.

[22] Holmes, J. (2008). An introduction to sociolinguistics. (3 ${ }^{\text {rd }}$ ed.). Harlow, Essex: Longman.

[23] Holmes, J. (2013). An introduction to sociolinguistics (4 th ed.). Hoboken: Taylor and Francis.

[24] Kayambazinthu, E. (1995). The pattern of language use in Malawi: A sociolinguistic investigation into selected areas. Unpublished $\mathrm{PhD}$ thesis, La Trobe University.

[25] Kumanireng, T. Y. (1994). Language shift and maintenance in East Nusa Tenggara (ENT). Paper presented at ALI 94 Workshop - Language Shift and Maintenance in The ASIA-Pacific Region. Wenner Gren Foundation for Antropological Research and Australian Institute of Aboriginal and Torres Straits Islander Studies.

[26] Kuncha, R. M., \& Bahula, H. (2004). The role of attitude in language shift and language maintenance in a new immigrant community: A case study. Retrieved from http://www.crie.org.nz/research paper/H.Bathula wp1.pd/

[27] Kurniasih, Y. (2006). Gender, class and language preference: A case study in Yogyakarta. In Keith, A., (Eds.), Selected Papers from the 2005 Conference of the Australian Linguistics Society.

[28] Labov, W. (1972). Sociolinguistic patterns. Philadelphia: University of Pennsylvania Press.

[29] Ladegaard, H. J. (2000). Language attitudes and sociolinguistc behavior: Exploring attitude-behaviour relation in language. Journal of Sociolinguistics, 4(2), 214- 233.

[30] Liebscher, G., \& Dailey-O'Cain, J. (2009). Language attutudes in interaction. Journal of Sociolinguistic, 13(2), 195-222.

[31] Marnita, R. (2006). Perilaku berbahasa masyarakat Minangkabau dan pengaruhnya terhadap pemakaian ungkapan sebagai media pendidikan informal keluarga. Artikel Penelitian Dasar. Padang: Andalas University.

[32] Marnita, R., \& Suraiya, L. (2011). Indonesian language performance of Minangkabau bilingal children. International Journal on Social Science, Economics and Art, 1(4), 299-303.

[33] Musgrave, S. (2011). Language shift and language maintenance in Indonesia. Retrieved from http://users.monash.edu.au/ smusgrav/publications/LMLS_Indonesia_Musgrave.pdf

[34] Navis, A. A. (1986). Alam terkembang jadi guru: Adat dan kebudayaan Minangkabau. Jakarta: PT Grafiti Pers.

[35] Nadra. (2000). Perkembangan fonem bahasa melayik purna dalam dialek-dialek bahasa Minangkabau. In Purwo, Bambang, K., \& Anton, M. M. (Eds.), Kajian Serba Linguistik: Untuk Anton Moeliono, Pereksa Bahasa, 334-356. Jakarta: BPK Gunung Mulia.

[36] Oktavianus, \& Marnita, A. R. (2008). Perilaku berbahasa masyarakat Minangkabau dan pengaruhnya terhadap pemakaian ungkapan sebagai media pendidikan informal keluarga. Linguistik Indonesia, 26(2), 219-232. Jakarta: Unika Atmajaya.

[37] Oktavianus. (2005). Kias dalam bahasa Minangkabau (Unpublished doctoral dissertation). Bali: Universitas Udayana

[38] Pasaman in Figures. (2009). Pasaman Statistics. 
[39] Ravindranath, M., \& Abigail, C. C. (2014). Can a language with millions of speakers be endangered? Journal of the Southeast Asian Linguistics Society, 7, 64-75.

[40] Russell, A. S. (2000). Language shift and maintenance: A socio-cultural approach (Unpublished doctoral dessertation). La Trobe University.

[41] Setiawan, S. (2013). Children's Language in a bilingual community in East Java. (Unpublished doctoral dessertation). University Western of Australia.

[42] Salim, A., \& Zulkifli. (2004). Minangkabau dalam catatan sejarah yang tercecer. Padang: Yayasan Citra Budaya Indonesia.

[43] Smolicz, J. J. (1992). Minority language as core values of ethnic cultures. Maintenance and Loss of Minority Languages, 278-305.

[44] Sneddon, J. N. (2003). The Indonesian language: Its history and role in modern society. Sydney: UNSW Press.

[45] Sneddon, J. N. (2003). Diglossia in Indonesian. Bijdragen tot de Taal-, Land- en Volkenkunde, 159, 519-549.

[46] Stark, A. (2013). The matrilineal system of the Minangkabau and its persistence throughout history: A structural perspective. Southeast Asia: A Multidisciplinary Journal, 13, 1-13.

[47] Steinhauer, H. (1994). The Indonesian language situation and linguistics; Prospects and posibilities. Bijdragen tot de Taal-, Land- en Volkenkunde, 150(4), 755-784.

[48] Seong, M. P., \& Mela, S. (2003). Parents' attitudes toward heritage language maintenance for their children and their efforts to help their children maintain the heritage language: A case study of Korean-Canadian immigrants. Language, Culture, and Curriculum, 20(3), 233-235.

[49] Thamrin, T., \& Gani, M. H. H. (2008). Sosiolinguistik sistem sapaan: Teori dan sebuah model aplikasi. Padang: Bung Hatta University Press.

[50] Thamrin, T. (2016). Minangkabau language : Use and attitudes (Unpublished doctoral dissertation). La Trobe University, Australlia.

[51] Xue-hui, Z. (2003). Language use and language attitudes of Indonesian brides in Taipei city (Unpublished doctoral dissertation). National Chengchi University, Taiwan.

[52] Zhang, D. (2010). Language maintenance and language shift among Chinese immigrant parents and their second-generation children in the U.S. Bilingual Research Journal, 33, 42-60. 